\title{
Optimization of banana plantlets acclimatization by hydroponic cultivation
}

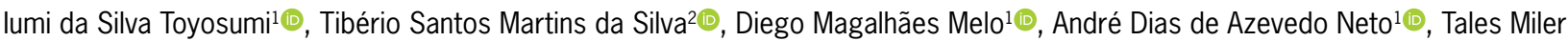 \\ Soares ${ }^{1}\left[\right.$, Maurício Antonio Coelho Filho ${ }^{2 *}$ (D)
}

\author{
'Universidade Federal do Recôncavo da Bahia/Núcleo de \\ Engenharia de Água e Solo, R. Rui Barbosa, n. 710 - 44380- \\ 000 - Cruz das Almas, BA - Brasil. \\ ²Embrapa Mandioca e Fruticultura, R. Embrapa, s/n, C.P. \\ 007 - 44380-000 - Cruz das Almas, BA - Brasil. \\ *Corresponding author <mauricio-antonio.coelho@embrapa.br>
}

Edited by: Mohammad Valipour

Received June 09, 2020

Accepted October 10, 2020
ABSTRACT: Acclimatization is the final phase of banana plantlet production by micropropagation. In this phase, the plantlets are grown in a protected environment with high demand for water, fertilizer and labor, until reaching the standard size and quality required for marketing. The aim of this study was to evaluate the possibility of reducing these costs and the duration of the acclimatization phase, using the hydroponic cultivation technique as compared to the conventional system. 'Prata-Anã' banana plantlet performance was measured for both systems under both tropical summer and winter conditions, based upon water and nutrient use efficiency and growing time of the plantlets. In both seasons, the plantlets produced hydroponically presented faster growth of both the shoot and root systems. There was a reduction of 12 days to reach the transplantation point, a significant reduction in plantlet production cost (fertilizers + water) and improved efficiency in space use with an expressive increase in the number of plantlets produced per square meter.

Keywords: Musa spp., soil-less cultivation, water use efficiency, growth

\section{Introduction}

The banana crop has high socioeconomic importance throughout the world (Alemu, 2017). According to statistics from the FAO (2020), banana exports contribute approximately US $\$ 12$ billion per year to the global economy and total banana production reached a volume of 116 billion $\mathrm{kg}$ in 2017. Average productivity has increased from $14,000 \mathrm{~kg} \mathrm{ha}^{-1}$ in 1993 to $20,000 \mathrm{~kg} \mathrm{ha}^{-1}$ in 2017 (FAO, 2018).

In addition to general crop management practices, the quality of the planting material is a crucial input for success in growing commercial bananas. Inputs may represent $70 \%$ of the banana production cost and the plantlets alone account for $36.49 \%$ of these costs (Cardoso, 2006; Tiwari et al., 2019).

Banana plantlets can be obtained by micropropagation whose main advantages, as compared to the traditional method, are the higher multiplication rate and better phytosanitary quality (Ortas et al., 2017; Wong, 1986). The last stage of banana micropropagation is the acclimatization phase, when the plantlets are still growing under protected environmental conditions until reaching adequate size and hardness for their transplantation to the field (Scarinari et al., 2009; Waman and Bohra, 2019).

During acclimatization, the plantlets are growing in pots containing special substrate, and have to be watered and fertilized regularly. During this period there is a significant demand for water and fertilizers, as well as labor (Navarro et al., 1994; Waman and Bohra, 2019). Because of this, it is important to find alternatives to optimize the use of resources and reduce the duration of this phase.

An alternative may be to adapt the conventional cultivation system to hydroponics, whose use has strongly increased in agriculture. This technique has been pointed out to have significant potential for contributing to food production to meet the needs of a population on the rise (Sardare and Adname, 2013). This system may optimize the use of space and time use, with earlier transfer of the plantlets to the field, as well as enabling automation, with positive outcomes on resource use efficiency in comparison with the conventional system (Corrêa et al., 2012; Treftz and Omaye, 2016).

Hydroponic cultivation of banana plantlets in the acclimatization phase has not been mentioned in the literature yet and its viability must still be determined. The objective of this work was to compare the performance of hydroponic and conventional systems for the acclimatization of commercial banana plantlets in two seasons.

\section{Materials and Methods}

\section{Place and general methodological aspects}

The experiments were carried out in a greenhouse of a biofactory of banana plantlets production, located in

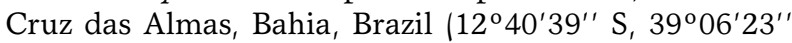
$\mathrm{W}$, altitude of $225 \mathrm{~m})$. The regional climate is classified as dry sub-humid, with average annual rainfall of 1,131 $\mathrm{mm}$, with moderate excess of rain in the winter, and average daily temperature of $23.9{ }^{\circ} \mathrm{C}$ (Silva et al., 2016).

The greenhouse was covered by an agricultural film with thickness of 150 microns along with a $50 \%$ shading screen.

Banana plantlets cv. Prata-Anã, obtained by in vitro propagation, were washed to remove the culture medium and then transplanted to trays with 128 cells, each with capacity of $0.0000225 \mathrm{~m}^{3}$ filled with inert material composed of coconut fibers. Two experiments were conducted to compare the performance of banana plantlets cultivated in conventional and hydroponic systems, the first during the winter and the second the summer, as described below. 


\section{Conventional acclimatization}

In the conventional cultivation system, the entire process was monitored daily by a technician in charge of plantlet production, according to the criteria used for large-scale commercial production. Along the acclimatization phase, plants are nourished by foliar fertilization divided into eight applications. For production of 10,000 plantlets by the conventional system, $0.0187 \mathrm{~L}$ of fertilizer solution was applied in each spray per plantlet, containing: $14 \%$ nitrogen, $7 \%$ phosphorus, $5 \%$ potassium, $1.5 \%$ magnesium, $0.1 \%$ boron, $1.5 \%$ manganese, $0.05 \%$ molybdenum and $2 \%$ zinc, plus $0.0625 \mathrm{~kg}$ of monoammonium phosphate (MAP) and $0.172 \mathrm{~kg}$ of ammonium sulfate.

The plants were irrigated manually, with variable frequency of 1.2 to 1.7 irrigations $\mathrm{d}^{-1}$, respectively, in experiment 1 and 2 . The number of irrigations per day was determined based upon the visual aspects of the substrate in the morning and afternoon. The substrate changes its color with increasing moisture content from light brown to dark brown.

\section{Hydroponic acclimatization}

The hydroponic system used in this study was adapted from the configurations of hydroponic systems applied commercially. The trays containing the explants were placed in recipients measuring $0.48 \times 0.26 \mathrm{~m}$ with a capacity of $0.02 \mathrm{~m}^{3}$. The recipients were placed on metal benches at a height of $1.2 \mathrm{~m}$ from the floor. The benches were positioned at a slope of $3 \%$ in Experiment I and flat in Experiment II.
The reservoir used had a capacity of $55 \mathrm{~L}$ and was attached to an electrical pump with a power rating of 34 $\mathrm{W}$ and flow of $0.0002333 \mathrm{~m}^{3} \mathrm{~s}^{-1}$, to move the water from the reservoir to the trays through polyethylene hoses $3 / 4$ inch in diameter. The same hoses were also used for the independent drainage system. The nutrient solution was distributed to the trays through microtubes $6 \mathrm{~mm}$ in diameter connected to the polyethylene hoses.

The volume of the nutrient solution lost by evapotranspiration was replaced by a system controlled by a float valve installed in the main reservoir and connected to another reservoir containing water from the municipal supply system. A valve was installed between the two reservoirs to support control over the moment of water replacement, providing replenishment every three days in the interval between the recirculation of the nutrient solution. The reservoir with replacement water consisted of a PVC tube with a diameter of $0.15 \mathrm{~m}$ and height of $1 \mathrm{~m}$. The structure had a ruler and a transparent microtube to allow monitoring of the volume of water replaced. The pumping system operated with fixed watering intervals of $15 \mathrm{~min}$, each lasting $15 \mathrm{~min}$. The hydroponic system is illustrated in Figure 1.

The nutrient solution was prepared according to the formulation developed by Furlani (1999) for leafy vegetables. The following ingredients were used to prepare 1,000 L of nutrient solution: $750 \mathrm{~g}$ of calcium nitrate, $500 \mathrm{~g}$ of potassium nitrate, $150 \mathrm{~g}$ of monoammonium phosphate, $400 \mathrm{~g}$ of magnesium sulfate, $0.15 \mathrm{~g}$ of copper sulfate, $0.30 \mathrm{~g}$ of zinc sulfate, $1.50 \mathrm{~g}$ of manganese sulfate, $1.80 \mathrm{~g}$ of boric acid, $0.15 \mathrm{~g}$

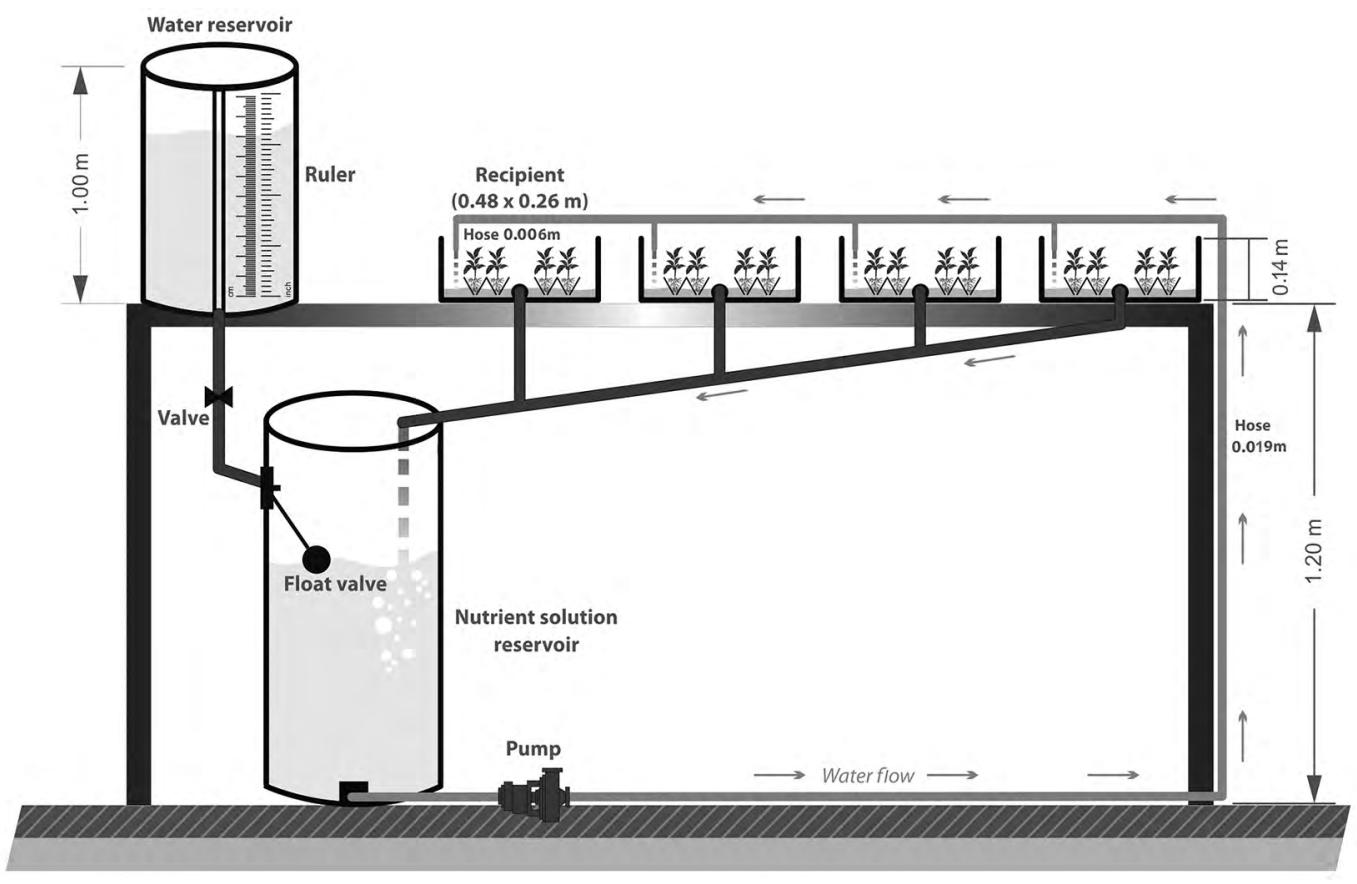

Figure 1 - Diagram of the hydroponic system used in the experiments. 
of sodium molybdate, and $16 \mathrm{~g}$ of iron Ethylenediamine tetraacetic acid (EDTA) at $13 \%$.

During plant growth the solution $\mathrm{pH}$ was monitored every two days with a pocket $\mathrm{pH}$ meter with automatic temperature compensation. Whenever the $\mathrm{pH}$ was below 6.0 or above 6.5 , it was corrected by applying a solution of $\mathrm{NaOH}$ or $\mathrm{HCl}$, respectively. Simultaneously, the electrical conductivity (EC) was measured with a bench meter. The reference adopted for replacement of the nutrient solution was a $25 \%$ decline in EC. However, neither of the two experiments presented any need to replace the solution.

\section{Experiment 1}

Experiment 1 was conducted in a completely randomized design with eight replications. The source of variation studied was the type of acclimatization, either hydroponic or conventional. The experiment lasted 25 days, at which time more than $50 \%$ of the plants had reached the harvest point corresponding to plant shoot height greater than 5 $\mathrm{cm}$ with total root adherence to the substrate.

This experiment was conducted during the winter. The environmental conditions in the greenhouse (average temperature and relative humidity) were monitored by sensors connected to a multiplexer. The variables were logged every $10 \mathrm{~min}$ and converted into hourly means. The average temperature during the experiment was $22.8^{\circ} \mathrm{C}$, with a minimum of $17.2^{\circ} \mathrm{C}$ and maximum of $31.4^{\circ} \mathrm{C}$, and the relative humidity varied from 40.7 to $100 \%$, with an average of $83 \%$.

The EC ranged from 2.08 to $1.91 \mathrm{dS} \mathrm{m}^{-1}$ from the start to the end of the experiment, a decrease of $8.17 \%$.

\section{Response variables}

Twenty-five days after the explants were transplanted to the trays, eight plantlets were sampled to evaluate the following growth variables: plant height $(\mathrm{m})$; leaf area $\left(\mathrm{m}^{2}\right)$; shoot fresh and dry weight $(\mathrm{g})$; total root length $(\mathrm{m})$ and length in diameter classes $(0-2$ and greater than 2 $\mathrm{mm})$; average root diameter $(\mathrm{mm})$; and root volume $\left(\mathrm{m}^{3}\right)$.

The shoots were separated from the roots and weighed on an analytical balance (accuracy of 0.0001 g) to determine fresh weight. The plant height was measured with a ruler and the leaf area determined as described by Potdar and Pawar (1991), using the length and width and the correction according to Eq. 1:

$$
\text { Total Leaf Area }=\frac{\Sigma[-0.0334+(L \times W \times 0.8402)]}{10,000}
$$

where: $L$ - length $(\mathrm{cm})$ and $W$ - width $(\mathrm{cm})$.

The shoots were dried in a forced-air oven at $65^{\circ} \mathrm{C}$ for $72 \mathrm{~h}$ to determine the dry weight on the analytical balance.

The roots were washed until complete removal of substrate and placed in jars with $30 \%$ alcohol, in which they were kept under refrigeration $\left(5^{\circ} \mathrm{C}\right)$ for evaluation. The root system was analyzed using a scanner and the data were processed by a suitable software program.

\section{Experiment 2}

This experiment employed a randomized block design in a $2 \times 7$ factorial scheme, with four repetitions, where each experimental unit was composed of 16 banana explants. The first factor denoted the type of acclimatization (conventional or hydroponic) and the second factor the time interval of biometric assessments, in days after transplantation (DAT). Growth was evaluated at $0,5,10,15,20,25$ and 30 DAT.

The experiment was performed in the summer. The meteorological data were collected by a system developed in the Arduino platform, employing sensors installed $2 \mathrm{~m}$ above ground level. Data were recorded every $10 \mathrm{~min}$. The average hourly temperature was $29.7^{\circ} \mathrm{C}$, varying between 23.2 and $43.2^{\circ} \mathrm{C}$ and the average relative humidity during the experiment was $69.2 \%$, with a of $31.7 \%$ and a maximum of $100 \%$.

The EC of the nutrient solution varied between 2.07 and $1.58 \mathrm{dS} \mathrm{m}^{-1}$ from the first to $30 \mathrm{DAT}$, resulting in a reduction of $23.67 \%$. However, when the plantlets were grown in the hydroponic system, ready at $18 \mathrm{DAT}$, the reduction of the electrical conductivity was $9.18 \%$ $\left(1.88 \mathrm{dS} \mathrm{m}^{-1}\right)$.

\section{Growth variables}

The same growth parameters were recorded as in Experiment I, namely: plant height; leaf area; fresh and dry shoot weight; total length and volume of the root system. In addition to these metrics, the absolute growth rate was also determined, indicating the increment in dry weight (Eq. 2).

$A G R=\frac{S D W f-S D W i}{N D}$

where: $A G R$ is the absolute growth rate $\left(\mathrm{kg} \mathrm{d}^{-1}\right)$; $S D W f$ the final shoot dry weight $(\mathrm{kg}) ; S D W i$ the initial shoot dry weight $(\mathrm{kg})$, and $N D$ the number of days of the experiment (30 days).

\section{Plantlet production efficiency}

The efficiency of the use of space in time (number of cycles per year) was derived from the ratio of the time interval (in days) for production of plantlets in each system and the number of days in the year. The plantlet production efficiency (number of plantlets $\mathrm{m}^{-2} \mathrm{yr}^{-1}$ ) was obtained from the ratio between the number of plantlets produced per square meter per year by each cultivation system.

At 30 DAT, the mortality (\%) of the plantlets was determined in the two acclimatization systems by a count of both the dead and the living as follows (Eq. 3): 


$$
M R(\%)=\frac{D S}{D S+L S} \times 100
$$

where: $M R$ - mortality rate, $D S$ - dead plantlets, $L S$ live plantlets.

\section{Volume of water and fertilizers applied}

The volume of water applied during the experiment in the conventional system was determined by recording the flow through the hose $\left(1.55 \times 10^{-4} \mathrm{~m}^{3} \mathrm{~s}^{-1}\right)$. This allowed for determining the number of plantlets irrigated in a 1 min period, obtaining an average of 3.2 $\times 10^{-6} \mathrm{~m}^{3}$ per plant irrigation, with a frequency of 1.7 irrigations $\mathrm{d}^{-1}$.

The volume of water used for replacement in the hydroponic system was obtained by applying the volumes of water recorded between the replacement events, and taking into consideration the time interval in days, as expressed in Eq. 4.

$V=\frac{(L f-L i) \pi D^{2}}{4 n \Delta t} 10^{3}$

where: $V$ - the volume applied $\left(\mathrm{m}^{3}\right.$ per plant $\left.\mathrm{d}^{-1}\right) ; L f-$ the final water level in the automatic supply reservoir $(\mathrm{m}) ; \mathrm{Li}$ - the initial water level in the automatic supply reservoir $(\mathrm{m}) ; D$ - the internal diameter of the automatic supply reservoir $(\mathrm{m}) ; \Delta t$ - the time interval between readings (days); and $n$ - the number of plants cultivated in the tray in time interval $\Delta t$.

The water use efficiency $\left(\mathrm{m}^{3}\right.$ per plantlet) was calculated as the ratio between the volume of water applied and the shoot's dry weight of the plantlets.

The efficiency of fertilizer use efficiency was calculated as the accrued cost of fertilizer application to 10,000 plants during the plantlet cultivation cycle.

\section{Statistical analysis}

In Experiment 1, the means of the treatments were compared by the paired T-test $(p<0.05)$, after transforming the data to $\log (x)$ when necessary to satisfy the prerequisites for the statistical test used.

In Experiment 2, the data were submitted to analysis of variance using the Exp.Des.pt in the R Core Team software package (version 4.0.2). The means of the variables between the acclimatization methods were analyzed by the F-test at a probability of $p<$ 0.05. For a comparison between the evaluation periods, linear and polynomial regression models were fitted, taking into account the coefficient of determination and presenting if significant at least $p<0.05$ level (Ftest). Where interaction of the factors was detected, the variables in each factor were separated. The mortality percentages were compared by the unpaired $\mathrm{T}$-test at $5 \%$ significance.

\section{Results}

The plantlets grew faster in the hydroponic acclimatization process than in the conventional one under the same microclimatic conditions.

\section{Experiment I}

Effects of the acclimatization method on shoot fresh and dry weight, plant height, total leaf area $(p<0.01)$ and total root system length $(p<0.05)$ (Figure 2) were evident, but no effect on the root system volume $(p$ $=0.0854)$ was detected. The use of the hydroponic acclimatization of 'Prata-Anã' banana plantlets enabled increases of 126, 123, 127, 69 and $61 \%$ in the variables' shoot fresh and dry weight, total leaf area, plant height and total root system length, respectively.

There was a significant effect $(p<0.05)$ on the root length in the diameter interval class 0 to $2 \mathrm{~mm}$ (Figure 3). Plants acclimatized in the hydroponic system presented a smaller proportion of roots with a small diameter, with a tendency for higher production of roots in all diameter classes evaluated (Figure 3).

\section{Experiment II}

\section{Growth variables}

In this experiment, in addition to the isolated effect of the acclimatization method on plantlet growth, as observed in Experiment I, there was interaction between the acclimatization method and date of evaluation (days after transplantation) for plant height, leaf area, shoot fresh and dry weight $(p<0.01)$ and total root system length $(p$ $<0.05)$. The root system volume was influenced only by the time factor $(p<0.01)$.

Plant height, shoot fresh and dry weight, leaf area and total root system length of the plantlets increased progressively during the experimental period, with linear and polynomial fits as a function of time after transplantation (Figure 4). However, the growth rate was higher for the plantlets grown in the hydroponic system compared to the conventional system. At $30 \mathrm{DAT}$, the hydroponic system produced increases in these variables of $31,76,37,120$ and $38 \%$, respectively, as compared to conventional acclimatization.

It is important to note that according to the regression equations (Figure 4), at 18 DAT the plantlets grown in the hydroponic system had reached the same average height as that reached under conventional acclimatization at 30 DAT, accelerating development of the upper system by 12 days. For shoot fresh weight, this result was also attained at 18 DAT, while for shoot dry weight and total root system length these results were achieved at 24 DAT and for leaf area at 16 DAT. The absolute average growth rates by dry weight were 0.008422 and $0.005465 \mathrm{~kg} \mathrm{~d}^{-1}$, respectively, for the hydroponic and conventional acclimatization. 

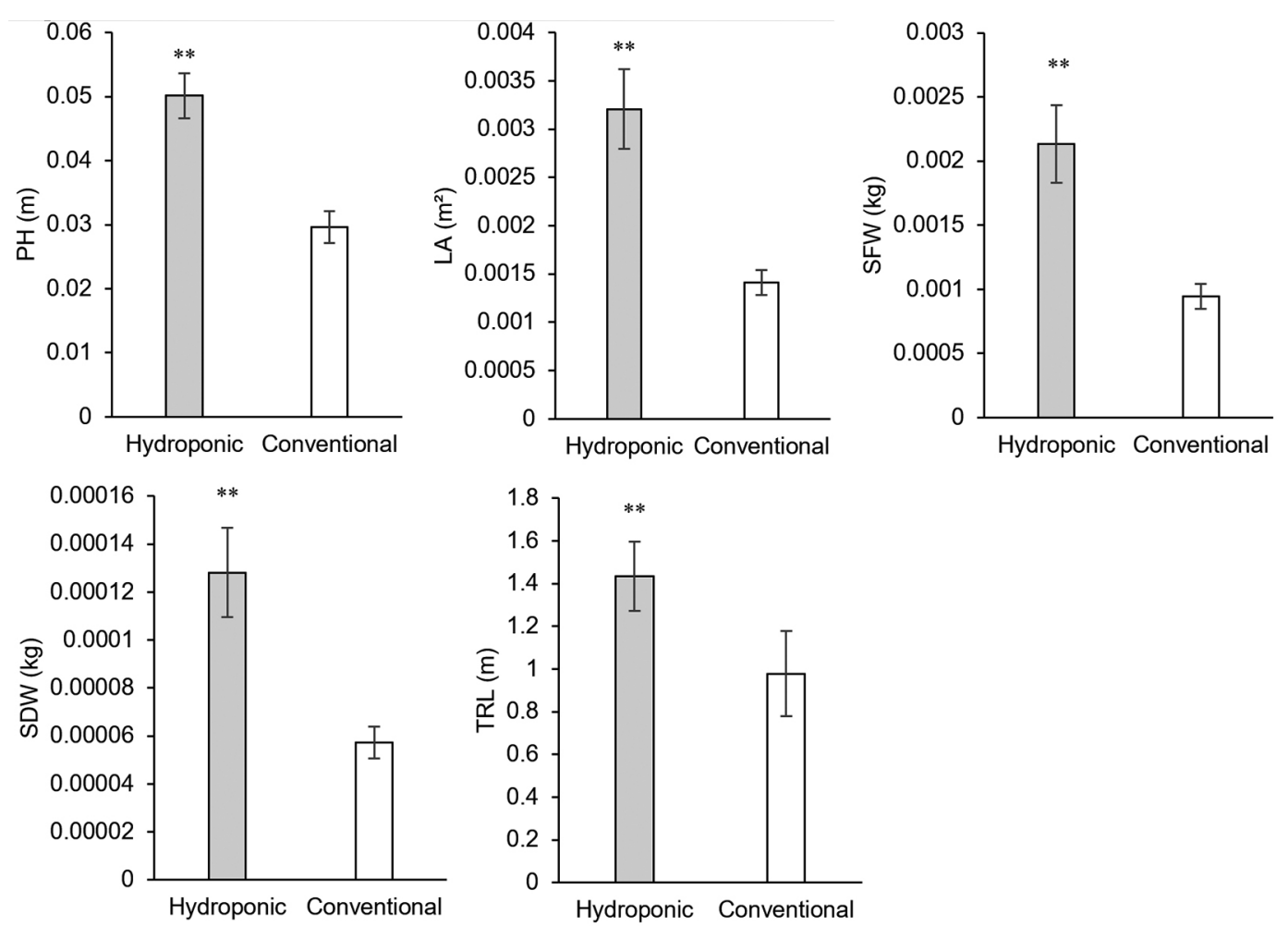

Figure 2 - Plant height (PH), leaf area (LA), shoot fresh weight (SFW) and shoot dry weight (SDW), and total root system length (TRL) of 'Prata-Anã' banana plantlets 25 DAT grown conventionally and hydroponically. Means of eight repetitions and respective standard errors. ${ }^{*}$ significant at $1 \%$ by the T-test.

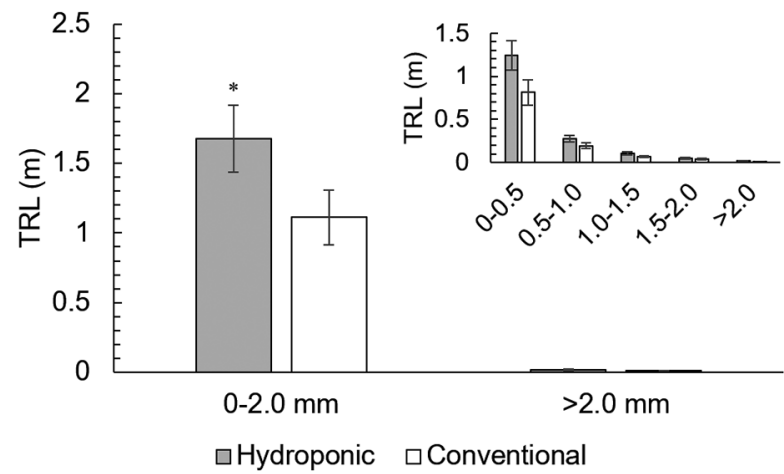

Figure $3-T R L=$ Total root system length in diameter classes and in classes with smaller intervals. ${ }^{*}$ significant at $5 \%$ by the T-test.

\section{Plantlet production efficiency}

The main criterion usually applied for determination of plantlets at adequate selling point is their height, in addition to the substrate totally filled with the roots as a more qualitative variable. Thus, we chose plant height as the criterion to determine the readiness for sale. Applying this criterion, the estimated efficiency of space utilization over time was 20.3 cycles $\mathrm{yr}^{-1}$ for hydroponic acclimatization and 12.2 yearly cycles for the conventional system. This means an increase of approximately $66 \%$ in the number of plantlets produced in a year by using hydroponic acclimatization. The plantlet harvest points were determined to be 18 and 30 DAT for the hydroponic and conventional system, respectively.

As regards plantlet production efficiency, taking into consideration 897 plantlets $\mathrm{m}^{-2}$, we estimated potential outputs of 18,119 and 10,943 plantlets $\mathrm{m}^{-2}$ $\mathrm{yr}^{-1}$ for the hydroponic and conventional systems, respectively. The respective mortality rates at 30 days after transplantation were $4.3 \%$ and $18.4 \%$ (Figure 5) for the hydroponic and conventional systems.

\section{Volume of water and fertilizers applied}

Water consumption to produce 10 thousand plantlets was $1.634 \times 10^{-4} \mathrm{~m}^{3}$ per plant for the conventional system and $6.440 \times 10^{-5} \mathrm{~m}^{3}$ per plant in the hydroponic system, providing a reduction of $60.58 \%$ during the cycle of 18 and 30 , respectively. Water utilization efficiency was much higher for the hydroponic system as, on average, for each liter of water $0.002216 \mathrm{~kg}$ of shoot dry weight was produced, whereas in the conventional system only $0.001273 \mathrm{~kg}$ of shoot dry weight was obtained for one liter of water used, a difference of $74.08 \%$ between the systems studied. 

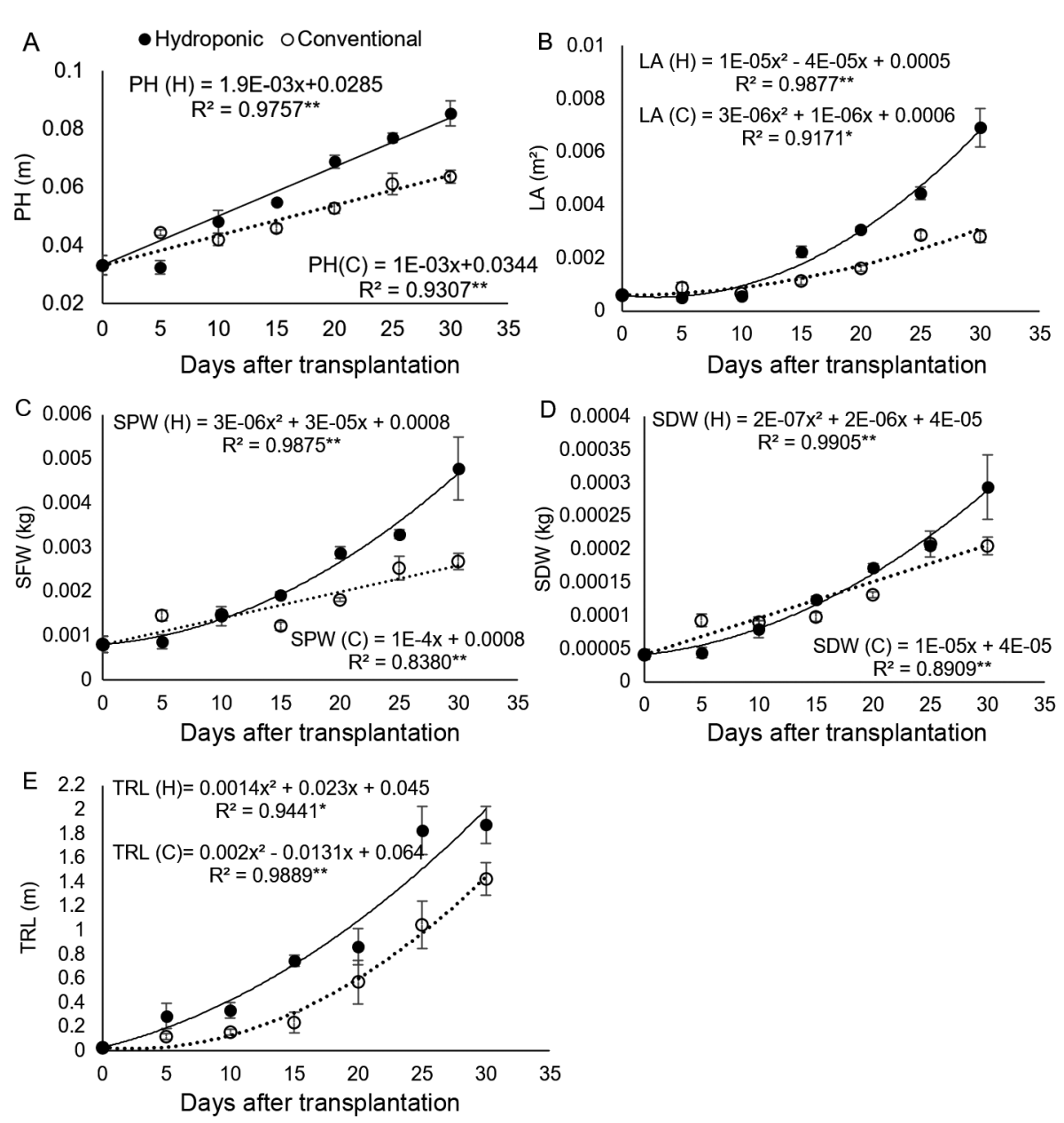

Figure 4 - Plant height (PH, A), leat area (LA, B), shoot tresh weight (SFW, C), shoot dry weight (SDW, D) and total root system length (TRL, E) of banana plantlets under conventional $(\mathrm{C})$ and hydroponic acclimatization $(\mathrm{H})$ in function of days after transplantation. ${ }^{* *}$ significant at 0.05 level and * significant at 0.01 level according to the $\mathrm{F}$ test.

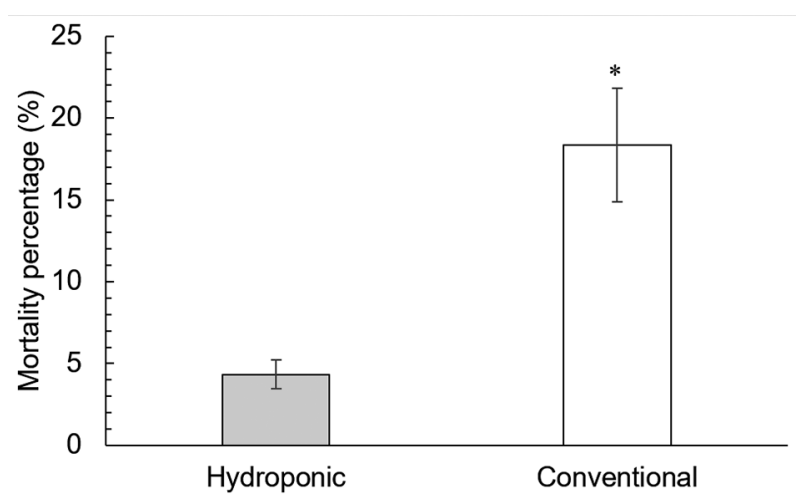

Figure $\mathbf{5}$ - Mortality percentage of banana plantlets by the two acclimatization systems. * significant at $5 \%$ by the unpaired Ttest.

The total cost of water and fertilizers used to prepare the nutrient solution for the production of 10,000 banana plantlets was $46.3 \%$ higher in the hydroponic system. On the other hand, the overall cost of the hydroponic acclimatization system was $57.6 \%$ lower than that of the conventional system, when taking into account the plants' nutrient uptake as assessed by electrical conductivity variation of the nutrient solution at 18 DAT (Table 1, Figure 6).

\section{Discussion}

In both experiments, we observed faster increases in the variables shoot fresh and dry weight, leaf area, plant height and total root system length of banana plantlets cultivated under the hydroponic system in comparison to the conventional system (Figures 2, 3 and 4). We suggest that this plantlet growth acceleration is due to the greater availability of water and nutrients in the hydroponic system than in the conventional one, as has also been reported by Jensen (1997), Rouphael et al. (2018), Sardare e Admane (2013) and Savvas (2003) for many agricultural species.

The nutrient solution used in the hydroponic system contains high concentrations of nutrients, which promote faster growth. In this respect, Taiz et al. (2014) 
Table 1 - Costs of water and fertilizers for acclimatization of 10,000 'Prata-Anã' banana plantlets in the conventional and hydroponic systems.

\begin{tabular}{|c|c|c|c|c|c|c|}
\hline \multirow{3}{*}{ Inputs } & \multicolumn{2}{|c|}{ CONVENTIONAL } & \multicolumn{4}{|c|}{ HYDROPONIC } \\
\hline & \multirow{2}{*}{ Quantity } & \multirow{2}{*}{ Cost (US\$) } & \multicolumn{2}{|c|}{ Preparation of the solution } & \multicolumn{2}{|c|}{ Water and fertilizers consumed $(9.18 \%$} \\
\hline & & & Quantity & Cost (US\$) & Quantity & Cost (US\$) \\
\hline 1. Water applied (L) & 1.634 & 2.1273 & 644 & 0.8376 & 644 & 0.8376 \\
\hline Subtotal (US\$) & & 2.1273 & & & & 0.8376 \\
\hline \multicolumn{7}{|l|}{ 2. Fertilizers } \\
\hline Fertilizer solution (mL) & 18.75 & 0.1734 & - & - & - & - \\
\hline $\operatorname{MAP}(g)$ & 62.5 & 0.1200 & 157.2 & 0.3007 & - & - \\
\hline Ammonium sulfate $(\mathrm{g})$ & 172 & 0.2048 & - & - & - & - \\
\hline Calcium nitrate (g) & - & - & 786 & 1.1310 & - & - \\
\hline Potassium nitrate (g) & - & - & 524 & 0.9631 & - & - \\
\hline Magnesium sulfate (g) & - & - & 419 & 0.3672 & - & - \\
\hline Copper sulfate (g) & - & - & 0.157 & 0.0005 & - & - \\
\hline Zinc sulfate (g) & - & - & 0.314 & 0.0013 & - & - \\
\hline Manganese sulfate (g) & - & - & 1.572 & 0.0295 & - & - \\
\hline Boric acid (g) & - & - & 1.886 & 0.0092 & - & - \\
\hline Sodium molybdate (g) & - & - & 0.157 & 0.0240 & - & - \\
\hline Iron EDTA $13 \%$ (g) & - & - & 16.8 & 0.1716 & - & - \\
\hline Subtotal (US\$) & - & 0.4963 & - & 3.0018 & - & 0.2749 \\
\hline TOTAL (US\$) & & 2.6236 & & 3.8394 & & 1.1125 \\
\hline
\end{tabular}

MAP = monoammonium phosphate; EDTA = iron Ethylenediamine tetraacetic acid.
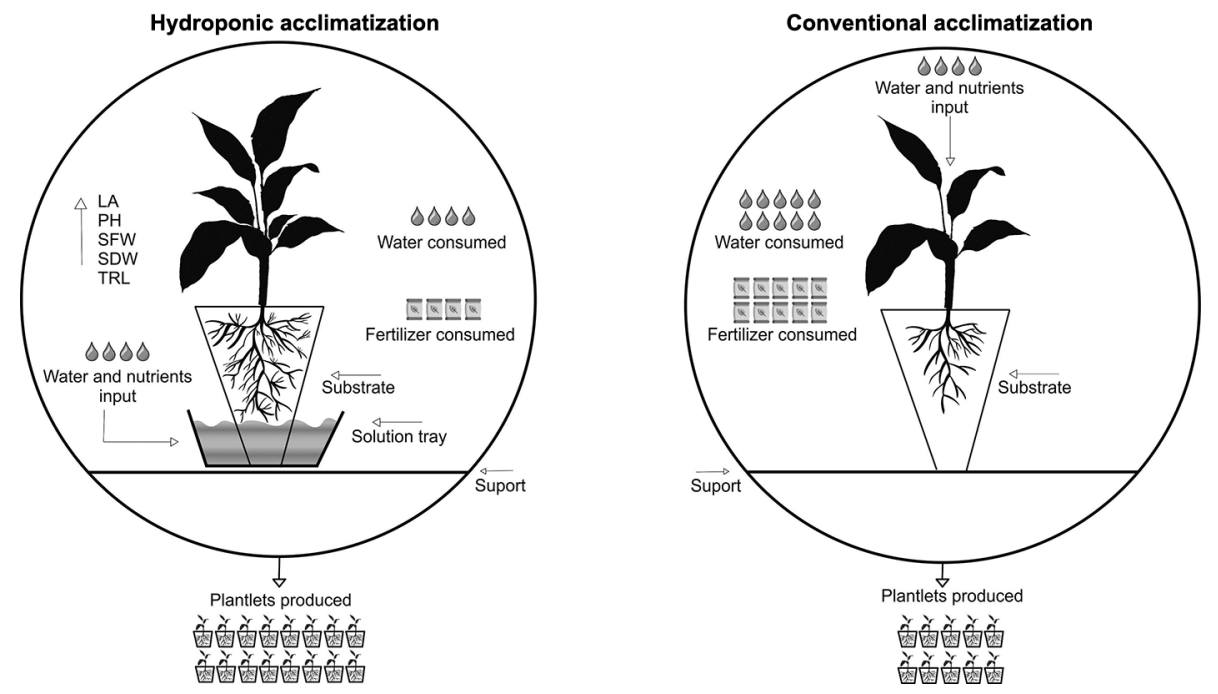

Figure 6 - Banana Plantlets production under hydroponic and conventional acclimatization.

reported that modern nutrient solutions contain the highest concentrations of nutrients possible without causing toxic and saline effects, which leads to high growth.

Additionally, under the conventional system used in this study, representing a typical commercial system for acclimatization of banana plantlets, the irrigation and fertilization are performed manually, often lacking uniformity, and are less frequently applied when compared to the hydroponic system, in which the nutrient solution was offered automatically every 15 min in carefully controlled doses (AlShrouf, 2017).
The absence of a significant difference between the treatments studied regarding root system volume may be related to a smaller allocation of photoassimilates to the roots, giving priority to the shoots, due to the low demand for root production in media containing high nutrient concentrations (Taiz et al., 2014), as in the case of hydroponic production.

On the other hand, we suggest that the greater root system length in the hydroponic treatment, without a difference in volume, was a result of the greater production of roots with smaller diameters. Higher production of roots with smaller diameters is desirable 
in the production of plantlets since it increases the chances of survival in the field due to the greater vigor of the plants (Wu et al., 2016).

The regression equations generated (Figure 4) indicated that the plantlet harvest point for sale was reached earlier, at 18 days after transplantation, under the hydroponic system, a reduction of 12 days in the acclimatization period. This result was expected which represents a greater number of plantlets to be produced per time unit in the same space, an increase of about $65 \%$ as compared to the conventional system. This also reduces the need for labor due to both the faster plantlet production and the automation feasibility (WoottonBeard, 2019).

Similar results were reported by Castellane and Araújo (1994), who observed for lettuce, bell pepper and tomato annual productivities of 52,16 and $18 \mathrm{t} \mathrm{ha}^{-1}$ $\mathrm{yr}^{-1}$, when grown in a conventional field system, and yields of 313,96 and $375 \mathrm{t} \mathrm{ha}^{-1} \mathrm{yr}^{-1}$ when cultivated in hydroponics, respectively, due to the faster growth cycle.

The higher water use efficiency in the hydroponic system corroborates Putra and Yuliando (2015) and Sardare and Admane (2013), all reporting that the closed-cycle hydroponic system is more efficient in water use due to the recapture of the nutrient solution not used by the plants to the reservoirs at the end of watering for subsequent reuse.

When counting the quantity of fertilizers used in the nutrient solution, the hydroponic system resulted in a higher production cost based on the water and fertilizers. However, only part of the fertilizers was used providing a cost reduction opportunity (Table 1). This reduced use of fertilizers in the hydroponic system was the result of recycling the nutrient solution, since the nutrients were readily available to the roots and none were lost to lixiviation because of the closed system (Savvas, 2003).

To the best of our knowledge, this is the first article reporting the acclimatization of banana plantlets in a hydroponic system for commercial purposes. For banana, hydroponics has only been used to understand aspects of uptake of nutrients, toxic elements and pollutants (Cornelis et al., 2012).

The results found in this study, carried out in partnership with a biofactory for the production of banana plantlets to supply the Brazilian market, are noticeably positive considering the growth acceleration of the plants promoted by the hydroponic acclimatization, resulting in faster production of banana planting material. In addition, the system proposed reduces cost due to lower volumes of water and fertilizers consumed and less labor needed. In spite of the higher initial costs for the implementation of the hydroponic system, over the long term the return is higher due to the greater automation and more efficient use of inputs and space in time, as has been reported for other crops (Sardare and Admane, 2013).

\section{Conclusions}

The use of the hydroponic system yielded a significant reduction in the time needed for acclimatization of banana plantlets, more efficient use of space in time and lower demand of water compared to the conventional system.

\section{Acknowledgments}

The authors would like to thank the Coordination for the Improvement of Higher Level Personnel agency (CAPES) (Process 88882.424487/2019-01) for the scholarship granted to the first author. We thank the financial research support granted to the sixth author, the Brazilian National Council for Scientific and Technological Development (CNPq) (Process 312796/2018-8). We are grateful for the financial support of Embrapa Cassava and Fruits and Campo Biotecnologia Vegetal Ltda. The authors thank Domingo Haroldo Rudolfo Conrado Reinhardt for his critical reading of the manuscript. We also thank Anapaula Rosário Lopes for the graphic design support.

\section{Authors' Contributions}

Conceptualization: Coelho Filho, M.A.; Toyosumi, I.S. Data acquisition: Toyosumi, I.S. Data analysis: Coelho Filho, M.A.; Toyosumi, I.S. Design of methodology: Coelho Filho, M.A.; Toyosumi, I.S.; Silva, T.S.M. Software development: Silva, T.S.M. Writing and editing: Coelho Filho, M.A.; Toyosumi, I.S.; Soares, T.M.; Azevedo Neto, A.D.; Melo, D.M.

\section{References}

Alemu, M.M. 2017. Banana as a cash crop and its food security and socioeconomic contribution: the case of southern Ethiopia, Arba Minch. Journal of Environmental Protection 8: 319-329.

AlShrouf, A. 2017. Hydroponics, aeroponic and aquaponic as compared with conventional farming. American Scientific Research Journal for Engineering, Technology and Sciences 27: 247-255.

Cardoso, C.E.L. 2006. Production cost = Custos de produção. Available at: http://www.agencia.cnptia.embrapa.br/ Agencia40/AG01/arvore/AG01_21_41020068055.html [Accessed Dec 18, 2018] (in Portuguese).

Castellane, P.D.; Araujo, J.A.C. 1994. Cultivation without soil-Hydroponics = Cultivo sem solo-Hidroponia. FUNEP, Jaboticabal, SP, Brazil (in Portuguese).

Corrêa, R.M.; Pinto, S.I.C.; Reis, E.S.; Carvalho, V.A.M. 2012. Hydroponic production of fruit tree seedlings. p. 225-244. In: Asao, T., ed. Hydroponics: a standard methodology for plant biological researches. IntechOpen, London, UK.

Cornelis, J.T.; Kruyts, N.; Dufey, J.E.; Delvaux, B.; Opfergelt, S. 2012. Understanding root uptake of nutrients, toxic and polluting elements in hydroponic culture. p.153-180. In: Asao, T., ed. Hydroponics: a standard methodology for plant biological researches. IntechOpen, London, UK. 
Food and Agriculture Organization [FAO]. 2018. Banana facts and Figures. Available at: http://www.fao.org/economic/est/ est-commodities/bananas/bananafacts/en/\#.XtpXNTBKjIU [Acessed May 6, 2020]

Food and Agriculture Organization [FAO]. 2020. Banana market review. Available at: http://www.fao.org/3/ca9212en/ca9212en. pdf [Accessed May 6, 2020]

Furlani, P.R.; Silveira, L.C.P.; Bolonhezi, D.; Faquin, V. 1999. Hydroponic plant cultivation $=$ Cultivo hidropônico de plantas. Instituto Agronômico, Campinas, SP, Brazil (in Portuguese).

Jensen, M.H. 1997. Hydroponics. HortScience 32: 1018-1021.

Navarro, C.; Teisson, C.; Côte, F.; Ganry, J. 1994. Effects of light intensity and $\mathrm{CO} 2$ concentration on growth of banana plants (Musa AAA, cultivar 'Petite Naine') in vitro and subsequent growth following acclimatization. Scientia Horticulturae 60: 41-54.

Ortas, I.; Rafique, M.; Akpinar, C.; Kacar, Y.A. 2017. Growth media and mycorrhizal species effect on acclimatization and nutrient uptake of banana plantlets. Scientia Horticulturae 217: 55-60.

Potdar, M.V.; Pawar, K.R. 1991. Non-destructive leaf area estimation in banana, Scientia Horticulturae 45: 251-254.

Putra, A.; Yuliando, H. 2015. Soilless culture system to support water use efficiency and product quality: a review. Agriculture and Agricultural Science Procedia 3: 283-288.

Rouphael, Y.; Kyriacou, M.C.; Petropoulos, S.A.; Pascale, S.; Colla, G. 2018. Improving vegeTable quality in controlled environments. Scientia Horticulturae 234: 275-289.

Sardare, M.D.; Admane, S.V. 2013. A review on plant without soilhydroponics. International Journal of Research in Engineering and Technology 2: 299-304.
Savvas, D. 2003. Hydroponics: a modern technology supporting the application of integrated crop management in greenhouse. Food, Agriculture \& Environment 1: 80-86.

Silva, T.S.M.; Coelho Filho, M.A.; Coelho, E.F. 2016. Meteorological bulletin of the conventional station of Cruz das Almas, BA: variability and climatic trends = Boletim meteorológico da estação convencional de Cruz das Almas, BA: variabilidade e tendências climáticas. Embrapa Mandioca e Fruticultura, Cruz das Almas, BA, Brazil (in Portuguese).

Taiz, L.; Zeiger, E.; Moller, I.M.; Murphy, A. 2014. Plant Physiology and Development. Sinauer Associates, Oxford, UK.

Tiwari, I.L.A.; Verma, M.; Gupta, S.; Devi, S. 2019. Impact of technology adoption on production and productivity of banana. Journal of Pharmacognosy and Phytochemistry 8: 2032-2034.

Treftz, C.; Omaye, S.T. 2016. Hydroponics: potential for augmenting sustainable food production in non-arable regions. Nutrition \& Food Science 46: 672-684.

Waman, A.A.; Bohra, P. 2019. Factors governing success in shoot tip culture of bananas with special reference to mixed genomic groups: an overview. Erwerbs-Obstbau 61: 9-21.

Wong, W.C. 1986. In vitro propagation of banana (Musa spp.): initiation, proliferation and development of shoot-tip cultures on defined media. Plant Cell, Tissue and Organ Culture 5: 159166.

Wootton-Beard, P. 2019. Growing without soil: an overview of hydroponics. Farming Connect, Aberystwyth, Wales.

Wu, Q.; Liu, C.; Zhang, D.; Zou, Y.; He, X.; Wu, Q. 2016. Mycorrhiza alters the profile of root hairs in trifoliate orange. Mycorrhiza 26: 237-247. 